Scholedge International Journal of Multidisciplinary \& Allied Studies

ISSN 2394-336X, Vol.04, Issue 01 (2017)

Pg 11-16.

DOI: 10.19085/journal.sijmas050102
Published by: Scholedge Publishing

www.theSCHOLEDGE.org

Email: editorial@thescholedge.org

(C) Publisher

\title{
The African Writer and Commitment in Art: a Critical Discourse of Ngugi Wa Thiong'o's Literature of Commitment, Social Vision and Stylistic Use of Satire in Matigari
}

\author{
Bie, Precious Dumka \\ Ignatius Ajuru University of Education \\ Rumuolumini, Port Harcourt, Rivers State, Nigeria
}

\begin{abstract}
African writers like Ngugi Wa Thiong'o have not relented in their portraiture of the dehumanizing plights of the working class. Ngugi is a revolutionary writer conditioned by the colonial, post-colonial and neocolonial socio-political and economic quagmire and experiences surrounding him, and as such he has no choice than to use art as an avenue of expressing his ideology and vision about the multifaceted problems as pictured in his society. This paper therefore, examines commitment in literature with particular focus on the Kenyan writer, Ngugi wa Thiong'o's committed literature and social vision, his stylistic use of satire. The conceptual framework is Marxism using Ngugi's Matigari. The study as a close textual analysis adopts the descriptive design.
\end{abstract}

Keywords: Ngugi wa Thiong'o, literature of commitment, neo-colonialism, Kenya ideology, Marxism, social vision and satire.

\section{Introduction}

Ngugi wa Thiong'o has remained very significant on the literary landscape of Africa and world literature. Ngugi registered his footprint with the publication of Weep not Child (1964). As a major critic of the postcolonial experiences of his homeland Kenya in particular and Africa in general, Ngugi has used art as an instrument for social transformation from the exploitation and dehumanization of the masses by the neocolonialists. In this vein, Kaur puts: Ngugi lays bare the neo-colonial exploitation by the African compradors class on the natives in terms of economic, political and educational means' (137). This is the core reason Ngugi's works are polemical as they lash out at the sickening exploitation, marginalization and the sordid conditions the masses of Kenya are unremorsefully subjected.

The irritation of the fact that the departure of the Whiteman after Kenya independence from the political arena did not ameliorate the social conditions of the people resulted in a feeling of disillusionment. Through a close textual study of Ngugi's Matigari is revealed the extant monster of colonial masters who have metamorphosed into neo-colonialist parasites and vampires sucking the blood of the nation and her people. As a committed writer, Ngugi is vociferously at the vanguard of criticizing the harsh and unsympathetic realities of the capitalist system of economic operation in the country which leaves the proletariat (workers) impoverished and allows he-who-reaps-where-he-never-sowed grabbed the products of he-who-sowed and go to sleep on an empty stomach (M. P. 97). Raphael (cited in Rauna, 2016, P. 27) examines class exploitation as an unequal exchange between an employer and workers. Capitalists exploit workers by paying them low wages and make more profit on the workers' expenses. Workers have a class interest in choosing a socialist system of property relations over a capitalist one, Rauna (27). Thus, Ngugi addresses this unequal, dialectical relationship in terms of labour and benefits of labour existing between the proletariat and the bourgeoisie. 
African writers have greatly portrayed the infinite inhuman conditions prevalent in African societies. In Matigari, Ngugi satirizes the exploitative nature of black leaders and delineates their insensitivity to the general yearnings of the people, children inclusive. The debilitating socio-political Kenyan landscape drastically informs Ngugi's revolutionary socialist stance as his works convey Marxist ideology. Afolayan writing on Matigari succinctly submits, 'Matigari... is also considered ... as an archetypical blueprint of revolution' (59).It is the untold hardship, destitution and nonchalant attitude of the political classwhich created in the masses the consciousness and acknowledgement that revolution is the cataclysm of the most necessary change - revolution. This belief assumes a crescendo in Matigari and spurs the workers to chant:

\author{
Victory shall be ours! \\ Victory shall be ours! \\ Victory shall be ours! \\ Victory shall be ours! (175).
}

As a conscientious artist, it is his will to challenge and change the political status quo of his country. Ngugi stands to do anything artistically possible to bring about revolution that would usher in a people-oriented and empathetic government; a government that is sensitive to the feelings of the people. This assertion is in consonance with the view expressed by Ebong that:

The writer as a revolutionary thinker strives always to change the world, to redirect and channel the minds and conscience of his people towards a new set of values, a higher awareness or reality. (cited in Amala, 2013 P. 42)

It is accurate to stress here the fact that Ngugi is an ardent revolutionary writer who would stop at nothing in ensuring that his society, the poor masses of Kenya are treated equally in the distribution of the products of the land. The view is that until the workers inKenya attain good standard of living, the war against capitalism would continue.

\title{
Research Design and Methodology
}

A research design is the arrangement of conditions for collecting and analysis of data in a manner that aims to combine relevance to the research purpose with economy of procedure. Kothari (qtd. in Mwihia\&Ogogo 2014, P. 65). It is the guide or blueprint used in data collection before the researcher carries out his research. It is the framework that specifies the nature of investigation (Amadi, 2002P.51). This study as a close textual analysis adopts the descriptive design. This particular design paves the way for the researcher to critically peruse the text under study in order to render his view and opinion on NgugiWaThiong'o's literature of commitment, social vision and stylistic use of satire in Matigari. The researcher carried out a critical analysis of the text under study to analyze the extent to which it conveys the social vision of the author. Primary data was collected from the primary source while the secondary data was gotten from various critical texts. All these sources of information were critically read and analyzed with particular interest paid to those relevant to the study.

\section{Theoretical Framework}

This study is grounded in Marxist criticism or dialectical approach which grew out of sociological criticism. Marxist criticism, in its diverse forms, grounds its theory and practice on the economic and cultural theory of Karl Marx (1818-83) and his fellow thinker Friedrich Engels (1820-95) Abrams (181).Karl Marx's theory of dialectical materialism expresses that as far as existence is concerned, man is in need of certain basic objects with which to survive on this earth such as food, clothing and shelter (Worgu, 93). In order that these needs may be available to man, he enters into 'associations' or 'partnership' with his fellow humans. But as time grows out of its shell, there is the tendency of contradictions and misunderstanding setting in this relationship with the class -those possessing the means of production call the bourgeoisie the (upper class of society) oppressing the 'proletariat' or 'wage-earning working class' who supply the ordinary labour. These contradictions then culminate into societal conflict which can only be settled through a revolution or the overthrown of the capitalists and finally leads to a classless society or communism. In this vein Ikechi summarizes that:

In its militant form, Marxism requires the writer to use his art as a weapon of social change preaching a state of equilibrium, exposing the falsities of bourgeois culture and by so doing, becoming a propagandist literature for the destined society in which all men will be happy and free... (67). 
The above submission gives credit to the fact that a close reading of all Marxist works reveals them to be propagandist in nature. This is consequent upon the fact that, they all assume a polemical position in exposing the hard social realities prevalent in spatial-temporality of a particular society. Marxism is premised on class struggle. We would not therefore, hesitate to state here categorically that Marxism is class struggle and class struggle is Marxism.

\section{NgugiWa Thiong'o and Literature of Commitment}

Ngugi takes centre stage when the issue of committed literature is discussed in African literature. Literary critics and scholars are aware of this position. Although formalists and structuralists in the West advocate 'art for art's sake' this position is maintained because of their socio-economic and political situations and responses of their governments to the plights of their citizens. In Africa without commitment art would lose its second value - that of educating the masses about the state of affairs and presenting modalities on putting things right. In Africa, the phrase 'art for art's sake' may not be our watchword because Africa as a continent is still developing and literature would continue to serve its purpose of interfering positively with social issues that affect the masses. In this development, we would concur with the trio:Chinweizu, Jemie and Ihechukwu who convincingly submit:

The function of the artist in African, in keeping with our traditions and needs, demands that the writer, as a public voice, assume a responsibility to reflect public concerns in his writing...because in Africa we recognize commitment is mandatory of the artist. (qtd. In Nnolim 225)

Thus, the issue of 'social commitment' of art can never be over-emphasized as far as African literature is concerned. The African writer whether established or emerging is aware of this fact. The role of literature in Africa seems to be more of education, creating consciousness in the masses about the ills and prevailing injustices and circumstances of the society perpetrated by certain institutions of the society than mere entertainment or aesthetics. However, the most captivating fact about the African writer is that no matter how committed and closer they may be to their works, a thread of aesthetics runs through their works. They endeavour to keeping with the tradition professed by Nwihia and Ogogo but not to an extent that, 'the aim of every work of art among others is to communicate and have an aesthetic impact upon the reader (63).

A committed literature we would say is that which aims at expressing the engagement or preoccupation (social vision) of the author without deviation and erect a map on the modality(ies) of confronting or eliminating the social problems which his works delineates. This does not mean a work must be revolutionary before it can map out modalities to solving social problems. NgugiWaThiong'o is a committed writer. According to Amadi the committed writer, 'is one who consciously uses his writing as an instrument for furthering the cause (sic) he believes in' (22). This further echoes the statement of SaroWiwa that ...the writer's responsibility is to tell the truth as he sees it' (13). The committed writer is more passionate and outspokenly expressive about his ideological stance or proposition. We find in Nguigi's works proven militant authorial voice overshadowing and superseding that of his heterodiegetic narrator what we would call an 'open authorial intrusion.' On this note critic like Nnolim has affirmed, '...the most infuriating artistic blunder by Ngugi in the novel [is] the all too evident lack of narrative distance between author and his subject matter'(53). The kernel of the issue is that Ngugi is very subjective in his artistic creation as a result of the socio-political and economic predicament in his society that to him feigning pretence and clinging to artistic poetics would become artistic sabotage.

Some critics are of the opinion that commitment in literature means prostitution of literature. However, we are aware connotatively or denotative of the fact that the words literature and prostitution are far apart semantically or metaphorically. We would rather submit here that commitment in art is not a prostitution of literature because in Africa the sole aim of art would not be achieved if the audience is merely obsessed with its aesthetic value than its education and transformation which can only spring up as a result of the writer's commitment. In emphasizing the significance, potency and position of literature of commitment, Amala states, 'these writers [African writers] are aware that writing a politically committed literature is the writer's weapon against injustice' (41).NgugiWaThiong'o is one of the prominent committed writers in Africa who believes what he writes and writes what he believes.

\section{NgugiWaThiong'o's Social Vision and Stylistic Use of Satire as Presented in Matigari}

Matigari is a social, industrial or working class novel. In another vein, it is a social protest novel and falls in the category of Proletarian fiction. The proletarian form of the social protest novel emphasizes an 
unequivocal revolution by the workers and oppressed of the society. The revolution stems from the state of servitude experienced by the factory workers such as we witness in Matigari.

Ngugi presents his social vision in Matigari by making a great choice of language in narrating the macrosocial negative experiences of the people of Kenya. His medium of presentation of the degradation on the Kenyan landscape is both mimesis and diegesis. His graphic exegesis of the social ills of the neocolonialists and compradors class is vocal and picturesque as he shows and tells us through his eponymous hero Matigarima Njiruunji, a freedom fighter and ardent patriot.

In Matigari, the author starts by articulating the revolutionary intent of his work through the technique of digenesis. The heterodiegetic narrator tells in the opening chapter:

He held an AK47 in his right hand. His left hand was raised to shield his face while he looked across the river, as he had often done over many years, across many hills and valleys, in the four corners of the globe(3).

Here the artist paints the picture of arms struggle that has existed even before the start of the narrative. The atmosphere here ostensibly and graphically explains revolution, revolt and rebellion. It is this particular ambiance which saturates Ngugi's works especially Matigari that prompts Afolayan to posit:

Ngugi's social vision is rallying the members of the working class to join together and fight for a better form of government than the one they were living under(20).

The author rallies round the working class and also strategizes the modality of their action. This is total commitment in literature of a high degree. He knows that the only means to transform the society to a better one is to overthrow the existing power and superstructure that be and erect another. Ngugi is practically committed in his social vision to the extent that his novels such as Petals of Blood and Devil on the Cross have similar theme and plot structure. The narratives are inconsonance just to ensure the message sinks down to the sub-consciousness of his audience. On this note, we would agree with Afolayan that:

The basis of 'commitment' is not only seen in the social value of a work of art but also in the capacity of the artist to delineate a vision of a way out of the social malaise mirrored (3).

Ngugi from the foregoing proposes the use of arms and bloodshed as the only solution to get the bourgeoisie aside. He advocates confrontational and disproves conversational approach because the oppressor does not understand such language of dialogue or 'passive résistance.'

Matigarima Njiruunji returns from the forests where he has been in combat with settler major Howard Williams the white colonialist who has confiscated his house and land, and John Boy, William's cook, the black stooge to find the son of Williams, Robert and John Boy Jr. still occupying the same house he has been fighting for all these years. The house and land here metaphorically refer to the wealth of the country. The possessors like their predecessors despise Matigari evident in his whipping twice by John Boy Jr. (M. 47).The presentation and integration of John Boy Jr. together with Robert Williams is an indictment on the colonial masters and their influence on the political and economic system of Africa. It is accurate to state here that African leadership failure and nonchalant disposition of her political class towards the masses is a direct negative influence of the colonialists who have metamorphosed to neo-colonialists with the black face as a camouflage.

The political, socio-economic and cultural decadence in the land touches on every one. In terms of the effect, all the poor masses are affected. In Matigari, we have three distinct categories of sufferers: men represented by Matigari and Ngarurowa Kiriro, the unionist murder by the police, a patriot named a 'madman' (M. 151), the women represented by Guthera and the children represented by Muriuki. The workers comprise all of them. Matigari and Ngarurowa Kiriro are hunted down for daring to raise their voice against exploitation, dehumanization and social injustices. Women like Guthera are sexually harassed and exploited in addition to the hardship and sorrow the capitalists have melted out to them. The children represented by Muriuki are homeless, underfed, exploited and left to sleep in discarded cars. According to the narrator:

They were now standing in an open space. They had left the storeyed buildings behind them. In front of them was a scrap yard where cars of 
all makes were stuffed with pieces of cardboard, plastic, papers, sacking cloth, almost anything. 'That is our village!' 'These wrecks?' 'Yes, they are our houses' (M. 15-6).

This is the picture that justifies the social vision of the author. Ngugi presents a country of political decadence and insensitivity; a country where men who seek after truth and justice are sent to psychiatric hospital for being mentally derailed; a country where reasonable people are termed madmen and huddled into cell(M. 122-123) and realities are termed delusions (M. 136). These situations provoke Matigari to state:

For I have seen that in our land today lies are decreed to be truth, and truth is decreed to be lies. Theft and corruption have become the order of the day (M. 137-138).

Ngugi's intention is for the audience to be acquainted with the social predicament which Kenya as a country has suffered in the hands of those he calls devil. It is then a truth that Ngugi's novels hold a mirror to his personal and social vision and expose the picture of the evolution of the African society from the colonial to the independent and the post-colonial status Pydah(108).

In communicating his social vision, Ngugi presents Matigari as a satire. Satire is a device used by a writer to lampoons the social ills and vices of the society. Thus, Matigari is a bitter, biting satire of the undulating Kenyan political landscape. Ngugi stylistically employs the element of invective in satirizing Kenyan social institutions. Invective is spoken or written, scathing expression design to cast aspersions or disgrace at a person or institution. The novel is replete with invectives which in turn form the basis of the humour and mockery in the face of serious subject matter. It is stylistically deployed and manipulated

As a literary cognoscente, Ngugi lampoons the religious institution represented by the Priest whom Matigari meets in his quest for where one can find justice and truth in the land, the educational institution and the media where Permanent Professors of History of Parrotology, the Ph.D. in Parrotology and the editor of the Daily Parrotry sing hymns from Songs of Parrotry(M. 107) which symbolically connotes those who belong to the academia and the media heaping encomium and panegyrics on the capitalists just like parrots, they only talk without taking necessary action for change to the benefit of all. Furthermore, he satirizes the security agent and the judiciary. The political institution is not left out. He ridicules political institution and her shenanigans. A case is the adulterous sexual relationship of the wife of the Minister for Truth and Justice and her driver. The satire then comes in the reportage of the event that transpired by the raised voice of two invisible interlocutors who report that the wife of the Minister together with her driver is attacked by thieves and her car stolen (M. 153). This particular incident among others evokes derision and laughter from the reader.

\section{Conclusion}

In bringing this discussion home, it a truism to say so far that attempt has been made to examine Ngugi's literature of commitment, his social vision and stylistic use of satire in Matigari and that NgugiwaThiong'o is a committed writer who has been consistent in the propagation of his ideology and social vision and as such has achieved in creating in his audience a particular consciousness.

\section{References}

[1] Abram, M.H., and Geoffrey Harpham.A Glossary of literary Terms. 9th ed. Boston: Thomas Wadsworth, 2005. Print.

[2] Amadi, Reginald. Research Methodology and Statistics. Port Harcourt: Amass, 2002. Print.

[3] Amadi, Elechi. "Problems of Commitment in Literature" Speaking and Singing (Papers and Poems). Port Harcourt: University of Port Harcourt Press, 2003. Print.

[4] Afolayan Sola, "NgugiWaThiong'o and His 'Mathe-logic' of Revolution in Matigari:Re-introducing Militia Struggle.” International Journal of English Literature Vol. 6(3) (2015): PP. 58-66. Print.

[5] Amala, Peace I. "Realism in Alex La Guma's A Walk in the Night."Icheke: Journal of the Faculty of Humanity Vol. 11, No. 1 (2013):PP. 41-50. Print.

[6] Ikechi, Emeka. Critical Technique. Port Harcourt: Edik Integrated Services, 2005. Print.

[7] Kaur, Hardeep. "Resistance and Betrayal in Ngugi's Petals of Blood and Devil on the Cross in the Context of Neo-colonialism.”South Asian Journal of Multidisciplinary Studies Vol. 2 Is. 3 (2014): PP. 137-139. Print.

[8] Mwetulundila, Rauna. "A Marxist Analysis of NgugiWaThiong'o's Novel Matigari. International Journal of Research in Humanities and Social Studies.Vol. 3, Is. 10, (2016).PP. 26-32. Print

[9] Nnolim, Charles."The Writer as Patriot.”Issues in African Literature. Lagos: Malthouse Press Limited, 2009. Print.

[10] ---, Structure and Theme in NgugiWaThiong'o'sA Grain of Wheat.” Approaches to the African Novel: Essays in Analysis. Lagos: Malthouse Press Limited, 1992. Print. 
[11] Pydah, Meena, "The Language of Discord in the Novels of NgugiWaThiong'o." Journal of English Language, Literature and Humanities Vol.1 Is. V (2014): PP. 108-120. Print.

[12] Saro-Wiwa, Ken. On a Darkling Plain: An Account of the Nigerian Civil War. Port Harcourt: Saros International Publishers, 1989. Print.

[13] Thiong'o,sNgugi, Wa. Matigari. USA: Heineman, 1982. Print

[14] Worgu, Geoffrey A. Literature and Literary Criticism: An Introduction. Port Harcourt: Nissi Books, 2006. Print. 